\title{
RADOSŁAW LOLO*
}

Akademia Humanistyczna im. A. Gieysztora

\section{ŚWIĘTY WLADYSLAW W PULTUSKU}

Przed kilku laty, kiedy prowadziłem badania nad dziejami Towarzystwa Jezusowego w diecezji płockiej w epoce przedrozbiorowej, natknąłem się na informacje o uroczystym przekazaniu pułtuskiemu kolegium jezuickiemu relikwii króla Węgier św. Władysława I Arpada (ok. I040-I095). Wówczas była to dla mnie wiedza poboczna i wątku tego nie rozwijałem. Ograniczyłem się więc wtedy wyłącznie do konstatacji, że los relikwii pozostaje obecnie nieznany ${ }^{1}$. Obchody 450-lecia sprowadzenia jezuitów do Pułtuska, zorganizowane w roku 20I6, przyniosły jednak szereg nowych faktów, które sprawiły, że temat ów wręcz należało podjąć obszerniej. Zainteresowani nim poważnie stali się bowiem także i Węgrzy, zwłaszcza, że w Györ od lat prowadzono intensywne poszukiwania brakujących części czaszki świętego. Wkrótce rozpoczęła się współpraca i badania, które przyniosły szereg ważnych ustaleń. Klimatowi badawczemu sprzyjał niewątpliwie także i fakt, iż rok 2017 ogłoszono na Węgrzech rokiem św. Władysława². Niniejszy artykuł jest więc pierwszą próbą przybliżenia okoliczności sprowadzenia relikwii św. Władysława do Pułtuska i ich późniejszych losów, aż do chwili obecnej³, ale po kolei...

\section{Kolegium jezuickie w Pultusku w drugiej połowie XVI wieku i jego znaczenie na edukacyjnej mapie Rzeczypospolitej}

Jezuici przybyli do Pułtuska w I566 roku. Inicjatorem ich sprowadzenia był biskup płocki Andrzej Noskowski. Gdy idzie o edukację w swej diecezji, biskup przejawiał szerokie ambicje i dużo energii, popartej zresztą nieczęstą w jego wypadku hojnością. Początkowo planował nawet założenie w biskupim Pułtusku samodzielnego uniwersytetu, o czym traktowała

\footnotetext{
* Radosław Lolo - dr hab. prof. AH - specjalizuje się w historii Mazowsza w epoce wczesnonowożytnej, ze szczególnym uwzględnieniem historii Kościoła katolickiego, dziejów mazowieckiej szlachty i mitów z nią związanych oraz dziejów miast mazowieckich. Współautor i współredaktor z H. Samsonowiczem m.in. tomu I Dziejów Puttuska (do roku 1795), t. II Dziejów Mazowsza. Pełni funkcję dyrektora Ośrodka Badań nad Mazowszem ATENA. Adres e-mail: lolor.j@poczta.onet.pl.

1 R. Lolo, Towarzystwo Jezusowe $w$ diecezji płockiej 1566-1773. Studium koegzystencji w dobie recepcji reformy trydenckiej, Pułtusk 2013, s. 83, przypis 7.

2 Wydarzeniom z okazji Roku Świętego Władysława oraz jego postaci poświęcono znaczną cześć czasopisma „Quo Vadis?” 47/2017.

3 O relikwiach tych krótko wzmiankowano jedynie u: E. Gorys, Leksykon świętych, Warszawa 2007, s. 386-387, J. Paszenda SJ, Budowle jezuickie w Polsce XVI-XVIII w., t. 2, Kraków 2000, s. 343; C. Lipka, Święty król węgierski Władysław, „Quo Vadis?” 47/2017, s. 12. Ogólniej, ale podobnie o św. Władysławie i jego związkach z Polską: C. Lipka, Święty król węgierski Władysław, w: Węgry-Polska, wspólne dziedzictwo, red. J. Zimny, Sandomierz 2007, s. 315-329 oraz J. Nastalska-Wiśnicka, Władysław I, Laszlo, Ladislaus, w: Encyklopedia katolicka, t. 20, Lublin 2014, s. 745.
} 
nawet konstytucja sejmowa I562/563 roku O szkołach, gdzie wprost zapisano: ,item o szkołę krakowską, poznańską i pułtawską, jako posłowie proszą, aby reformowane były, aczkolwiek to należy na urząd ich miłości księżej biskupów, którym tego prawo pospolite i przodkowie nasi zwierzyli, jako fondatorowie a nadawcy tych to szkół, wszkaże My w tej mierze księża biskupy i rektory napomniemy i zwierzchności Naszej tego doźrzemy, aby szkoły te w dobrej sprawie były"4. Ostatecznie w nowych gmachach szkolnych wzniesionych przez biskupa i solidnie uposażonych zagnieździła się jedynie filia Uniwersytetu Jagiellońskiego, działająca tylko do I564 roku. Po wybuchu zarazy w nadnarwiańskim grodzie, krakowscy uczeni już do Pułtuska nie powrócili, a biskup-fundator został z zatwierdzoną już przez kapitułę kolegiacką fundacją i opustoszałymi, a nowymi gmachami. Idąc śladem biskupa warmińskiego Stanisława Hozjusza, sprowadził więc do swego miasta jezuitów5

Kolegium, wspierane przez biskupa i funkcjonujące w jego mieście, w dodatku działające na niezbyt rozwiniętym pod względem sieci placówek edukacyjnych Mazowszu, zaczęło się rozwijać niezwykle szybko. W roku 568 miało już ponad 300 uczniów, a po ich rozpuszczeniu z powodu zarazy liczebność znów stale rosła, osiągając w roku 1573 stan 360 osób ${ }^{6}$. W gronie uczniowskim pojawiali się coraz częściej przedstawiciele naprawdę znamienitych rodów.

Jezuici w latach siedemdziesiątych XVI wieku dopiero zaczęli swój triumfalny pochód przez dzieje polskiej edukacji, a placówka pułtuska przez krótki czas była dla nich niezwykle istotna. Dopiero powstanie kolejnych kolegiów w dużych miastach, jak w Wilnie czy Poznaniu stopniowo zmieniało ten układ rzeczy. Nie ma się zatem co dziwić, że w pierwszych latach funkcjonowania zakon tu właśnie kierował wielu swych później wybitnych członków, którzy, ucząc i pracując duszpastersko w Pułtusku, rozsławili tutejsze kolegium na całą Rzeczpospolitą. Dość będzie wymienić w tym miejscu trzy wybitne postaci. Pierwszym rektorem kolegium pułtuskiego został Stanisław Rozdrażewski. Funkcję swą pełnił w latach 1566-I572. Należał on wówczas niewątpliwie do najlepiej wykształconych polskich jezuitów. Po wstąpieniu do Towarzystwa w I560 roku przez trzy lata studiował filozofię w Wiedniu, a przez rok teologię w Rzymie. Przez swego brata Hieronima - najpierw sekretarza wielkiego koronnego, a potem biskupa kujawskiego - miał Stanisław szeroki dostęp do elit politycznych Rzeczypospolitej. Sprawował między innymi funkcję kapelana hetmana Jana Karola Chodkiewicza7 ${ }^{7}$ Jeszcze wybitniejszą postacią był ks. Jakub Wujek. Solidnie wykształcony między innymi w Wiedniu, wstąpił do Towarzystwa Jezusowego w I565 roku w Rzymie. Tam przez dwa lata studiował teologię, ale potrzeby duszpasterskie spowodowały, że władze zakonne przerwały mu studia i oddelegowały do Pułtuska. Tu, można powiedzieć, narodził się talent wybitnego jezuity. W roku I568 w Pułtusku Wujek został wyświęcony na kapłana, a w dwa lata później uzyskał doktorat. Wykładał retorykę, a rozpoznawszy pilne potrzeby duszpasterskie zaczął pierwsze prace pisarskie i tłumaczenia. W roku I57I przeniesiono go

\footnotetext{
4 Volumina Constitutionum, t. II: 1550-1609, Volumen 1: 1550-1585, oprac. S. Grodziski, I. Dwornicka, W. Uruszczak, Warszawa 2005, s. 107.

5 R. Lolo, Powstanie i rozwój kolegium jezuickiego w Pultusku za poshugi biskupiej Andrzeja Noskowskiego, w: Renesans na Mazowszu. Andrzej Noskowski - biskup płocki, red. A. Koseski, K. Ostrowski, L. Sobieraj, PułtuskPłock 2011, s. 124-129.

6 R. Lolo, Towarzystwo Jezusowe..., s. 79.

7 Encyklopedia wiedzy o jezuitach na ziemiach Polski i Litwy 1564-1995, oprac. L. Grzebień SJ i in., Kraków 2004, s. 580.
} 
do Poznania, gdzie został rektorem kolegium. Później zaś także jako rektor trafił do kolegium wileńskiego, znacznie przyczyniając się do jego rozwoju, co jak wiadomo wkrótce zaowocowało nadaniu szkole wileńskiej statusu uniwersytetu ${ }^{8}$. Późniejsze prace nad tłumaczeniem Biblii przyniosły zaś Wujkowi wiekopomna sławę.

I wreszcie trzecia, niewątpliwie najsłynniejsza postać to ks. Piotr Skarga. Do Pułtuska trafił po studiach w Rzymie, dokładnie 9 czerwca I57I roku. „Światowy” już wówczas ks. Skarga nie był zachwycony Pułtuskiem, który przypominał mu rodzinny Grójec. Jego trzyletni okres posługi upłynął mu w dużej części na wyjazdach. W kolegium pełnił funkcje konsulatora i admonitora rektora. Poruczono mu również opiekę nad szpitalem i więzieniem. Był też głównym kaznodzieją kościoła. Ponieważ jezuici nie mieli wówczas jeszcze własnej świątyni, to z całą pewnością można powiedzieć, że w dzisiejszej bazylice kolegiackiej ks. Skarga wygłosił niejedno kazanie. Wielkie wrażenie wywarły zwłaszcza głoszone przez niego rekolekcje wielkopostne. Ksiądz Skarga opuścił Pułtusk w roku I573. W historii kultury polskiej zapisał się potem jako wybitny kaznodzieja królewski i autor wielu pism polemiczno-religijnych i politycznych. Mimo wielkiej sławy Skarga jednak nigdy o Pułtusku nie zapomniał. W swoim testamencie z roku I609 zapisał bowiem sumę I50 florenów na założone przez siebie w mieście Bractwo Miłosierdzia9.

Zatem i sławni potem w Rzeczypospolitej nauczyciele pułtuskiego kolegium i dynamiczny rozwój placówki w pierwszym okresie szybko wyrobiły szkole bardzo dobrą opinię. Ta zaś zaowocowała przyjęciem do szkoły niezwykłego ucznia.

\section{Andrzej Batory w Pultusku}

W końcu I578 roku monarcha sprowadził do Krakowa swego bratanka Andrzeja Batorego, z którym wiązał poważne plany dynastyczne. Młody Węgier przejawiał ponoć skłonności w kierunku powołania do stanu duchownego. Król zaś, po naradzie z nuncjuszem, zaczął szukać odpowiedniej dla bratanka szkoły. Choć przecież w ówczesnej Rzeczypospolitej porządnych szkół nie brakowało, rozważano również ewentualność kształcenia w kolegium pułtuskim. Wówczas do akcji włączyli się inni. Prowincjał polskich jezuitów ks. Franciszek Sunyer mocno zabiegał o ten zaszczyt, licząc na podniesienie rangi placówki. Niemała była też zasługa ówczesnego biskupa płockiego Piotra Dunina-Wolskiego. Były kanclerz koronny liczył, że siedziba jego biskupich dóbr, jako goszcząca królewskiego bratanka, zyska na randze, co przyczyni się do dalszego rozwoju Pułtuska. Nie bez znaczenia pozostawała również bliskość Warszawy i dworu monarszego oraz pozytywna opinia nuncjusza papieskiego o pułtuskim kolegium. Korzystna dla Towarzystwa Jezusowego decyzja zapadła w grudniu. Zaraz po Bożym Narodzeniu 1578 roku ksiądz Sunyer i biskup Wolski przywieźli więc młodego Andrzeja Batorego do Pułtuska.

Warto w tym miejscu dodać, że sprawa kształcenia Andrzeja Batorego, w którym rzeczywiście wówczas upatrywano kandydata na następcę Stefana I na tronie polskim, mocno leżała na sercu stolicy apostolskiej i była przedmiotem stałej troski najpierw nuncjusza

\footnotetext{
D. Kuźmina, Jakub Wujek (1541-1597) pisarz, thumacz i misjonarz, Warszawa 2004, s. 53-64.

9 R. Lolo, Ksiądz Piotr Skarga SJ w Puttusku. Fragment biografii na tle dziejów miasta, w: Piotr Skarga SJkaznodzieja z Mazowsza, red. A. Koseski, R. Lolo, Pułtusk 2013, s. 61-82.
} 
Giovanniego Andrei Caliagriego ${ }^{\mathrm{IO}}$, a po nim Alberta Bolognettiego ${ }^{\mathrm{II}}$, wielokrotnie wyrażana $\mathrm{w}$ ich korespondencji. Już $\mathrm{w}$ trakcie nauki starano się również $\mathrm{w}$ miarę możliwości zapewnić Andrzejowi godność kanonika kapituły warmińskiej, a następnie koadiuturę na to biskupstwo ${ }^{12}$.

Wiadomo, że królewski bratanek nie mieszkał z innymi uczniami, ale w oddzielnej, wcześniej przygotowanej kwaterze. Niestety ze źródeł nie wynika, co to było za miejsce. Domniemywać można, iż przyszły kardynał mieszkał w jakiejś kamienicy mieszczańskiej. Andrzej Batory pisał o miejscu swego pobytu w Pułtusku „mój dom”. Bratankowi królewskiemu zapewniono stosowne otoczenie rówieśników w osobach młodych szlachciców siedmiogrodzkich: Ferenca Forgácha i Gábora Dóczego. Odpowiednio starannie dobrano też osobę prywatnego preceptora Andrzeja Batorego. Posadę tę otrzymał sekretarz królewski i kanonik płocki Bartosz Zawadzki. Jak zaś wynika z dworskich rachunków całe otoczenie królewskiego bratanka w czasie pułtuskich studiów liczyło kilkanaście osób. W grupie tej byli nawet kucharz, dwóch woźniców i koniuszy. Nie skąpiono na futra i bogate tkaniny na stroje, mające podkreślić rangę ucznia. Andrzej Batory nie był więc z pewnością zwykłym uczniem. Ten przepych nie przeszkadzał wszak sumiennemu i zdolnemu młodemu Batoremu w odnoszeniu szybkich i ponoć większych niż pierwotnie się spodziewano postępów w nauce. A było nad czym pracować, bowiem szybko wyszło na jaw jak wielkie luki ma on w swej dotychczasowej edukacji. Batory miał więc dziennie w Pułtusku 4 lekcje łaciny: dwie gramatyki i dwie literatury łacińskiej, gdzie czytywał między innymi Cycerona czy Owidiusza. Dużą wagę przykładano też do nauki języków obcych, których lista wydaje się nam nawet dziś imponująca: polski, niemiecki i włoski należały do zajęć obowiązkowych. Nie zapomniano również o rozwoju religijnym Andrzeja i pilnowano, by pobożnie uczestniczył on w uroczystościach. Jedyną, na szczęście krótkotrwałą, przeszkodą okazała się choroba płuc, jak dopadła Andrzeja wiosną I58I roku. W roku I583 Andrzej Batory zakończył edukację w Pułtusku'3.

\section{Wdzięczność Batorych}

Okres edukacji Andrzeja Batorego w Pułtusku w ocenie króla Stefana I i królowej Anny Jagiellonki był czasem udanym i efektywnym. Edukacja monarszego bratanka przebiegła sprawnie, spokojnie i bez większych zagrożeń. Andrzej został dobrze przygotowany do mających go czekać w przyszłości wielkich wyzwań. Dlatego też wyrazy wdzięczności pary królewskiej dla pułtuskiego kolegium jezuitów także można uznać za nadzwyczajne. Król Stefan I uchodził za władcę tolerancyjnego. Rzadko kiedy w ogóle wspierał działalność Towarzystwa Jezusowego. A jeśli już to czynił, to głównie na wschodzie, widząc w jezuitach przydatnego sojusznika w umacnianiu tam swego władztwa. Stąd poparcie dla

\footnotetext{
10 Por: Monumenta Poloniae Vaticana (dalej: MPV), t. IV: I.A. Caliagri Nuntii Apos.[tolici] in Polonia epistolas et acta 1578-1581, oprac. L. Boratyński, Kraków 1915, nr: 62,67,80, 89, 100, 101, 110, 115, 129, 153, 173, 193 , 257, 259,270, 293, 321, 326, 331, 334, 335, 376, 380.

11 MPV, t. V: Alberti Bolonetti Nuntii Apostolici in Polonia epistolarum et actorum partem I: aa. 1581-1582, oprac. E. Kuntze, C. Nanke, Kraków 1923-33, nr: 114, 312, 334; t. VI: Alberti Bolonetti Nuntii Apostolici in Polonia epistolarum et actorum pars II: a. 1583, oprac. E. Kuntze, Kraków 1938, nr: 20, 29, 80, 98, 156, 166.

12 MPV, t. V, nr: 35, 81, 82, 118, 121.

13 I. Horn, Andrzej Batory, Warszawa 2010, s. 28-52.
} 
przekształcenia kolegium wileńskiego w uniwersytet ${ }^{14}$. Jeszcze dobitniej potwierdza to hojne wsparcie króla udzielone kolegiom jezuickim powstającym na obszarach nadgranicznych: w Połocku (I582) Dorpacie (I586) i w Rydze (I582) ${ }^{15}$. Natomiast w Koronie Stefan Batory w zasadzie nie udzielał wsparcia jezuitom. Nie tylko nie wspierał ich materialnie, ale też nie angażował się w spory, jak na przykład w słynną sprawę wokół Akademii Krakowskiej.

Wyjątek od tej reguły stanowi właśnie szczodrość króla wobec jezuitów pułtuskich, ewidentnie wynikająca z wdzięczności za efektywną edukację bratanka. Jezuici w Pułtusku od dawna borykali się z wykończeniem własnej świątyni. Stefan Batory nie tylko ofiarował niebagatelną sumę 300 zł na wykończenie kościoła pod wezwaniem Świętej Trójcy, ale również wraz z królową Anną Jagiellonką wziął udział w uroczystej konsekracji świątyni, dokonanej przez biskupa płockiego Piotra Dunina-Wolskiego w dniu 2I października I584 roku ${ }^{16}$. Nie był to jednak koniec wyrazów wdzięczności. Wiosną roku 1585 do Pułtuska ponownie przybył już wówczas jako kardynał Andrzej Batory. Po licznych oracjach uczniów kolegium wystawiono na cześć gościa sztukę Eripus. Na zamku biskupim wystawne przyjęcie zgotował Piotr Dunin-Wolski. Ponoć nawet zaplanował on niezwykle bogaty trzydniowy program pobytu kardynała Batorego w swym mieście. Jednak z barku czasu już następnego dnia Andrzej Batory wyruszył w drogę na Warmię ${ }^{17}$.

\section{Dar królowej Anny Jagiellonki}

Królowa Anna Jagiellonka pozostawała w tym czasie w nie najlepszych stosunkach z Andrzejem Batorym. Przed wspomnianym wyjazdem młodego kardynała na Warmię doszło w Warszawie wręcz do otwartego sporu między nią a Andrzejem ${ }^{18}$. Mimo to Anna Jagiellonka dokonała gestu spektakularnego, zapewne przemyślanego i chyba o głębszej, niż by się to mogło początkowo zdawać, wymowie. Otóż Anna Jagiellonka także przybyła do Pułtuska w I585 roku i została uroczyście przyjęta przez biskupa Dunina-Wolskiego. Przekazała wówczas kolegium jezuickiemu relikwię z głowy świętego Władysława Arpada. Historia kolegium opisuje to wydarzenie jako nadzwyczaj podniosłe. Celebra rozpoczęła się w kolegiacie, następnie w uroczystej procesji, podążającej przez długi pułtuski rynek przeniesiono relikwie do jezuickiego kościoła Świętej Trójcy i tam je zainstalowano. W Historii kolegium pultuskiego za rok 1585 zapisano: Actum e templum n[ost]rum tum sacro B.[eati] Ladislai Regis Ungariae capite, quod cum in thesauris Regiis sine honore iaceret. Sereniss[im] Poloniae Regina templo hiuc attribiut, tum possimis quibusda ornamientis, aulaeis ac cassulis, q[ae] eadem liberalissime donavit ${ }^{19}$. Zapis ten poddać należy analizie. Po pierwsze jezuici pułtuscy nie bardzo chyba jeszcze wówczas znali postać świętego, gdyż

14 Szeroko na ten temat: L. Piechnik, Dzieje Akademii Wileńskiej, t. 1: Początki Akademii 1570-1599, Rzym 1984.

15 R. Lolo, Oświata w Rzeczypospolitej w czasach panowania Stefana Batorego ze szczególnym uwzględnieniem jezuitów, w: Stefan Batory - król Rzeczypospolitej i książe Siedmiogrodu. Báthory István lengyel király ès erdèlyi Fejedelem, red. A. Körmendy, R. Lolo, Pułtusk 2008, s. 121-123.

16 J. Paszenda, dz. cyt., s. 341.

17 I. Horn, dz. cyt., s. 103.

18 Tamże, s. 105.

19 Archiwum Romanorum Societatis Iesu (dalej: ARSI), Polonia (dalej: Pol.) 50, Annuae et historiae Poloniae 1550-1660, f. 25. Tekst w wersji drukowanej: Annuae Litterae Sosietatis Jesu 1585. Provincia Poloniae, Romae 1587, s. 202-203. Autor korzysta z fotokopii rękopisu znajdującego siew zbiorach Biblioteki Naukowej Księży Jezuitów w Krakowie. 
użyli wobec niego określenia beatus. Co do pochodzenia relikwii, to podano niezwykle ważną informację, iż wcześniej znajdowała się ona w skarbcu królewskim, zresztą ,sine honore". Świątynia jezuicka otrzymała też od królowej wraz relikwiami bliżej nie opisane gobeliny, mające być może służyć ozdobieniu miejsca instalacji relikwii. Pojawia się pytanie o motywacje królowej. Wydaje się, że Anna Jagiellonka chciała swym darem podkreślić i upamiętnić rangę szkoły, gdzie skutecznie wykształcono in spe monarchę Rzeczypospolitej. Stąd właśnie dar w postaci relikwii króla, który na Węgrzech i nie tylko uchodził za wzór chrześcijańskiego władcy. Dar, co warte podkreślenia, „zalegający” w monarszym skarbcu, a doskonale pasujący do sytuacji.

Jak wynika z dość dobrze rozpoznanych dziejów relikwii świętego króla, spoczywały one długi czas w Wielkim Waradynie (węg. Nagyvárad, rum. Oradea). W I556 roku protestanckie wojska Jana Zygmunta Zapolyi splądrowały miasto, zbezcześciły sarkofag króla i sprofanowały jego relikwie. Najważniejszą z nich, czaszkę świętego, umieszczoną w zdobionej hermie zdołał uratować ks. Szegedi. Została ona następnie umieszczona na zamku Bathorych w Ecséd ${ }^{20}$. Nie ulega więc wątpliwości, że w drugiej połowie XVI wieku herma z głową św. Władysława rzeczywiście znajdowała się w gestii rodu Batorych. Anna Jagiellonka miała zatem dostęp do relikwii. Cezary Lipka ${ }^{21}$ przypuszcza nawet, iż w 585 roku przekazano pułtuskim jezuitom całą hermę z czaszką świętego. To tłumaczyłoby zapis kroniki kolegium, który literalnie brzmi: sacro B.[eati] Ladislai Regis Ungariae capite, quod cum in thesauris Regiis sine honore iaceret ${ }^{22}$. W tekście mowa jest zatem o całej głowie świętego, a nie o fragmencie czaszki. Lakoniczny zapis jezuitów nie wspomina jednak o ozdobnej hermie, w której umieszczona była czaszka. Według Cezarego Lipki po Io latach herma powróciła na Węgry, do Pozsony, pod troskliwą opieką ks. Napragy'ego ${ }^{23}$. Faktu tego niestety nie odnotowali kronikarze pułtuskiego kolegium jezuickiego.

\section{Dalsze losy relikwii w Pultusku}

Jeśli nawet rzeczywiście w Pułtusku przez dekadę znajdował się relikwiarz z czaszką świętego króla, który następnie powrócił na Węgry, to nie oznacza to wcale, że w jezuickim kościele Świętej Trójcy relikwii nie pozostawiono. Ksiądz dr Zoltán Lukácsi, obecny przy współczesnym, niezwykle wnikliwym badaniu czaszki króla, wielokrotnie podkreślał, że nosi ona znamiona dwukrotnego ,pobierania” z niej fragmentów. Przy czym jeden raz robiono to wyraźnie szybko, w sposób niezbyt delikatny ${ }^{24}$. Fakt, że relikwie św. Władysława nadal znajdowały się w Pułtusku ponownie potwierdzają kroniki kolegium pułtuskiego. W roku I634 wspomina się o wizycie w kolegium i oddaniu czci relikwiom złożonej przez najmłodszą z córek Zygmunta II Wazy, wówczas piętnastoletnią królewnę Annę Katarzynę Konstancję. Uroczystości trwały dwa dni, a mszę odprawił ówczesny biskup płocki Stanisław Łubieński ${ }^{25}$. Sama zaś królewna: argentu[m] regali liberalitate dignum pro recon-

20 C. Lipka, Święty król węgierski..., s. 11-12.

21 Tamże, s. 12.

22 ARSI, Pol. 50, f. 25.

23 C. Lipka, Święty król węgierski..., s. 12.

24 Wystąpienie na konferencji w Warszawie w dniu 10.10. 2017 r.: Rev. dr. Zoltán Lukácsi rector (teological High School and Seminary of Györ), Newest Scientific Researches on Head Relics (Herm) of Saint Ladislaus in Györ.

25 ARSI, Lit.[uania] 38 I-II, Historia, f. 199. 
dendo Capite S[ancti] Wladislai Ungariae olim regis obtilit ${ }^{26}$. Nie ma więc wątpliwości, że w Pułtusku nadal znajdował sie przynajmniej fragment relikwii z czaszki św. Władysława, któremu oddawano cześć. Chojnie wszak obdarowała je srebrami w I634 roku królewna Anna Katarzyna Wazówna. W roku I635 cześć relikwiom oddawał król Władysław IV Waza i ochmistrzyni dworu Urszula Ginger Meierin. Ofiarowali oni wówczas pułtuskim jezuitom cenne relikwiarze w formie figur półpostaciowych, odlane ze srebra, na relikwie św. Urszuli i św. Władysława ${ }^{27}$. Wedle Jerzego Paszendy SJ relikwiarz-herma dla św. Władysława miał nosić rysy portretowe króla ${ }^{28}$. Należy dodać, że król Władysław IV, choć sam może nie był wzorem pobożności, to rzeczywiście chyba otaczał czcią swego imiennego patrona. Jego to zasługą było wystawienie w kościele oo. kamedułów na warszawskich Bielanach kaplicy św. Władysława. Umieszczono w niej sztukaterię przedstawiającą sceny z życia tego świętego władcy. Zygmunt III Waza dokupił do niej jeszcze obraz przedstawiający św. Władysława ${ }^{29}$. Gestem w postaci obdarowania relikwii hermą przypominająca swój wizerunek Władysław IV wprost nawiązywał do sposobu przechowywania relikwii na Węgrzech i słynnej hermy.

Jak się wydaje w okresie późniejszym kult relikwii św. Władysława w Pułtusku osłabł. Jezuici, jak to dobitnie pokazują kolejne tomy historii kolegium, w coraz większym stopniu angażowali się w krzewienie kultu, wówczas jeszcze błogosławionego Stanisława Kostki ${ }^{30}$. Wzniesiony przez jezuitów, a konsekrowany w I7I8 roku, nowy kościół pod wezwaniem św. Piotra i Pawła wśród ołtarzy bocznych nie miał takiego, który byłby poświęcony św. Władysławowi, nic również nie wiadomo o szczególnym eksponowaniu relikwii ${ }^{31}$. Po kasacie Towarzystwa Jezusowego świątynię czasowo przejął kler diecezjalny jako filialną względem kolegiaty. W roku I78I, tuż przed przekazaniem kościoła benedyktynom sprowadzonym z Płocka, sporządzono kolejny, bardzo szczegółowy inwentarz. Nie wymienia on wśród precjozów wspomnianych wcześniej herm ani też interesujących z punktu widzenia tego artykułu relikwii ${ }^{32}$. Ogólnie zaś odnotowane w dokumencie nadzwyczaj ubogie wyposażenie w precjoza pojezuickiej świątyni nasuwa wniosek, że już wcześniej wszystkie cenniejsze paramenta zostały przeniesione najprawdopodobniej do skarbca bazyliki. Od tego czasu dzieje relikwii pułtuskich przez mniej więcej wiek pozostawały nieznane. Natomiast w roku I927 w zbiorczym zestawieniu relikwii znajdujących się wówczas w diecezji płockiej wspomina się, iż w kościele św. Piotra i Pawła w Pułtusku nadal znajdują się relikwie św. Władysława ${ }^{33}$. Natomiast współcześnie w aktach parafii zapisano ogólnie, że w pomieszczeniu nad zakrystią kościoła znajdują się „relikwiarze”. Relikwii nie identyfikowano, zaś na uzupełniającym

\footnotetext{
26 Tamże, f. 199.

27 Tamże, f. 220 v.

28 J. Paszenda, dz. cyt., s. 344, przyp. 32.

29 Ks. S. Mandziuk, Kościelne dzieje Bielan warszawskich, „Saeculum Christianum”, 2/2000, s. 51-65.

30 R. Lolo, Kult św. Stanisława Kostki w diecezji płockiej do 1773 r., w: Zwykli niezwykli. Kult świętych w diecezji tomżyńskiej. Katalog wystawy, red. B. Kalinowska, K. Mróz, Ostrołęka 2016, s. 83-90.

31 A. K. F. Wołosz, Opis kościoła pojezuickiego w Pułtusku z 1775 r., „Studia Mazowieckie”, 3/1998, z. 1-2, s. 104-119.

32 R. Lolo, Kolegium jezuickie w Puttusku pod koniec XVIII wieku. Przyczynek do historii zespołu architektonicznego, w: Polska-Europa - Afryka. Studia ofiarowane Profesorowi Bronisławowi Nowakowi w sześćdziesiąta piąta rocznicę urodzin, red. M. Dygo et al., Pułtusk 2007, s. 80-84.

33 Wykaz relikwii w diecezji płockiej, „Miesięcznik Pasterski Płocki”, 1927, nr 2, s. 324. Za wskazanie mi tej informacji dziękuję ks. dr Dariuszowi Majewskiemu - Dyrektorowi Archiwum Diecezjalnego w Płocku.
} 
dokumentację zdjęciu widnieją drewniane relikwiarze w formie wież $\dot{z}^{34}$ - zatem zupełnie inne niż herma na relikwie św. Władysława.

Z powyższych rozważań nasuwają się następujące wnioski:

I. W roku 1585 królowa Anna Jagiellonka uroczyście przekazała znajdujące się wówczas w gestii rodu Batorych (skarbcu królewskim) relikwie głowy św. Władysława jezuickiemu kolegium pułtuskiemu, co miało związek z odbywaną tam wcześniej przez Andrzeja Batorego edukacją.

2. Nie da się ustalić, czy była to wówczas cała czaszka w hermie, co sugerują zapiski, czy może tylko fragment czaszki - być może pozyskany w momencie, kiedy relikwie wracały na Węgry (ok. Io lat po przekazaniu przez królową Annę).

3. Istnieją przekazy źródłowe potwierdzające kult, jaki oddawano relikwiom św. Władysława w Pułtusku w XVII wieku, także w czasie odbywanych tu wizyt dynastów z polskiej linii Wazów (I634 - Anna Katarzyna Konstancja Wazówna i I635 Władysław IV Waza).

4. Podczas tych wizyt Wazowie składali szczodre wota, zaś Władysław IV i Urszula Meierin przekazali srebrne hermy na relikwie odpowiednio: św. Władysława i św. Urszuli.

5. Po kasacie jezuitów w kościele nie było już wspomnianych herm, co sugeruje, że podobnie jak inne kosztowne wyposażenie zostały one przeniesione w inne miejsce.

6. W roku 1927 poświadczono przechowywanie relikwii św. Władysława w kościele św. Piotra i Pawła, z czego wynika, że relikwie i herma zostały rozdzielone.

7. W momencie powstawania parafii, dziś pod wezwaniem św. Jana Pawła II (czerwiec $20 I$ r.), wśród wyposażenia kościoła parafialnego nie odnotowano ani relikwii, ani hermy.

\section{Odkrycia, ustalenia, wątpliwości}

W roku 2016 zaplanowano obchody jubileuszu 450-lecia przybycia jezuitów do Pułtuska. Jednym z ich elementów miała być wystawa okolicznościowa organizowana przez Muzeum Regionalne w Pułtusku. Ponieważ zebrane na wystawę materiały w głównej części stanowiły archiwalia i fotografie, postanowiono celem pozyskania zabytków materialnych dokonać rozeznania w kościele św. Piotra i Pawła. 24 sierpnia, w obecności ks. kanonika Sławomira Stefańskiego - proboszcza parafii, pracownicy Muzeum Regionalnego: Marian Kozicki, Monika Żebrowska i dyrektor Muzeum Andrzej Popowicz eksplorowali między innymi pomieszczenie nad zakrystią. Przy pozostałościach wnęki na szafę znaleziono między innymi uszkodzone trzy poduszki wykonane z płótna (wymiary: $37 \mathrm{~cm} \times \mathrm{I} 2 \mathrm{~cm} \times 6 \mathrm{~cm}$ i $37 \mathrm{~cm} \times$ II $\mathrm{cm} \times 6 \mathrm{~cm}$ ). Dwie poduszki obszyto zielonym, delikatnym materiałem z dużą starannością i dodano elementy zdobień. Dodatkowo zawierają one resztki zdobień w postaci wstęg i sztukowanych ornamentów. Do obu poduszek przytwierdzone były tabliczki w kształcie wstęg z łacińskimi napisami pismem nowożytnym Ex capitce S[ancti] Ladislai Regis. Na dwóch poduszkach znajdowały się przymocowane doń kości. Tabliczki z inskrypcjami i kości były trwale przytwierdzone bliżej nie określonym organicznym spoiwem (kości dodatkowo

\footnotetext{
34 Archiwum Rzymsko-Katolickiej Parafii św. Jana Pawła II w Pułtusku, mps: Protokót przekazania kościoła pod wezwaniem św. Piotra i Pawla wraz z domem parafialnym, garażami i dzialka, na której te obiekty zostaly zbudowane, s. 37.
} 


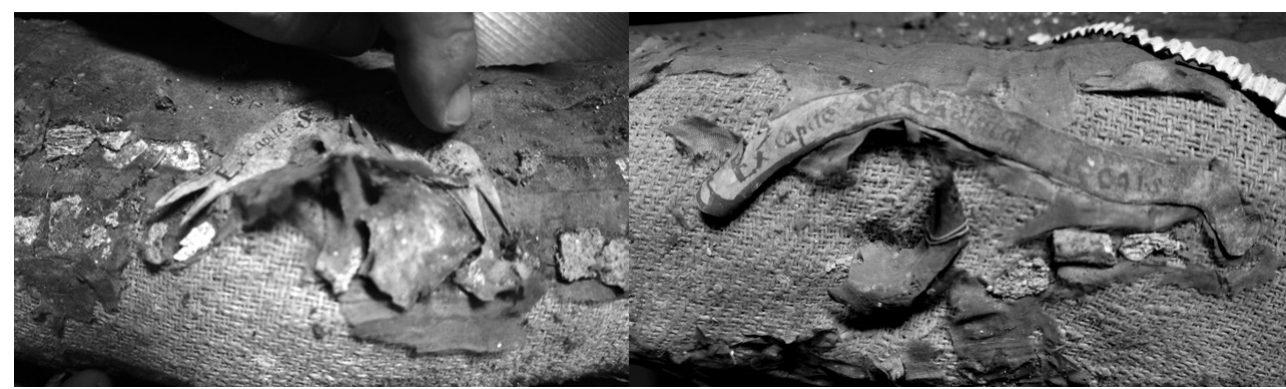

Il. I-2. Poduszki z fragmentami kości i napisami. Fot. M. Żebrowska-Muzeum Regionalne w Pultusku

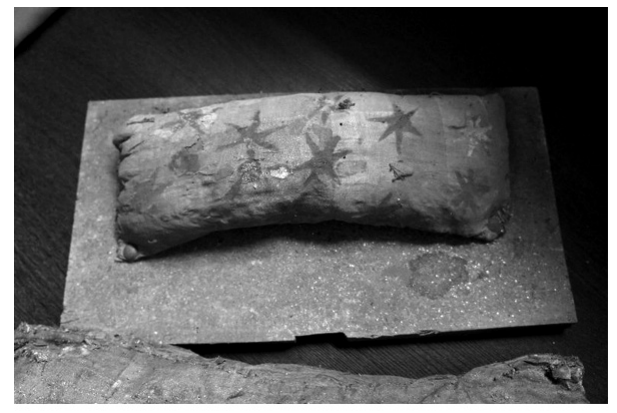

Il. 3. Trzecia ze znalezionych poduszek.

Fot. M. Żebrowska-Muzeum Regionalne w Puttusku

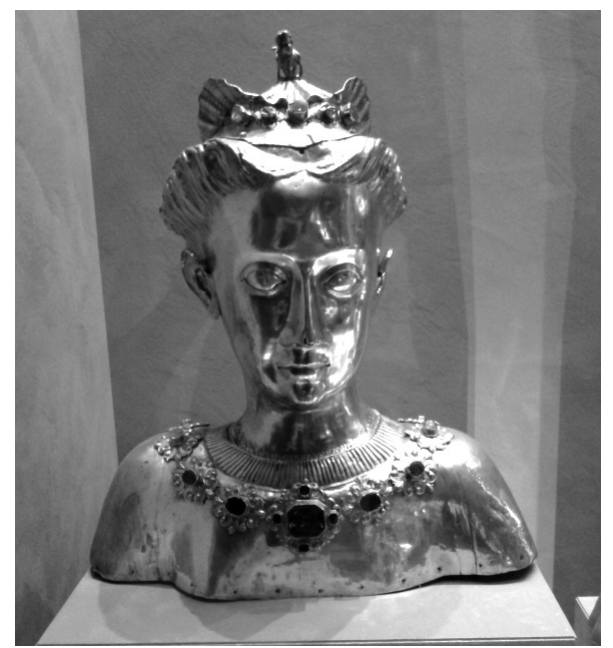

Il. 4. Relikwiarz hermowy św. Urszuli. Fot. Autor drutem), co w dużym stopniu wyklucza możliwość przypadkowego przemieszania artefaktów (il. I i 2).

Trzecia z poduszek (wymiary: $37 \mathrm{~cm} \times \mathrm{I} 2$ $\mathrm{cm} \times 6 \mathrm{~cm}$ ) wykonana była z wyraźnie innego materiału i nie zawierała śladów mocowania do niej kości. Za to zdobiły ją szczątkowo zachowane ornamenty w kształcie gwiazdek (il. 3). Ta właśnie poduszka ułożona była na drewnianej desce.

Po uzyskaniu stosownej zgody biskupa płockiego ks. Piotra Libery znalezione artefakty zostały poddane badaniom. W tym czasie znaleziskiem zainteresowali się przedstawiciele Ambasady Węgier w Polsce. Wsparcie okazane zwłaszcza przez Adrienne Körmendy - konsul Węgier pozwoliło zaś nawiązać kontakt z diecezją i wspomnianym już ks. dr Zoltánem Lukácsi, co z kolei umożliwiło podjecie ewentualnych analiz porównawczych z wynikami uzyskanymi w trakcie badań czaszki św. Władysława z Györ. Przeprowadził je zespół Instytutu Ekspertyz Sądowych im. Prof. dra Jana Sehna w Krakowie w 2017 roku. Poniżej przedstawiam jedynie wstępnie przekazane wyniki badań, gdyż pełen raport jest jeszcze w opracowaniu.

Wstępne wyniki wykazały, że znalezione kości nie należały do jednej osoby, a zdecydowana większość z nich pochodzi z okresu późniejszego niż wiek XII, czyli czas śmierci św. Władysława. Niestety nie były to żadne 
fragmenty żuchwy, której brakuje węgierskim relikwiom. Spośród znalezionych kości niemal żadna nie stanowiła brakującego elementu dostarczonej przez stronę węgierską drukowanej w technologii 3D kopii czaszki. Uwagę zwróciły natomiast niewielkie fragmenty w liczbie 7 elementów, z których największy miał rozmiar paznokcia męskiego u małego palca dłoni. Ustalono, że są to kości czaszki najprawdopodobniej ludzkiej. Niestety fragmenty te były w złym stanie i nie zawierały materiału genetycznego, który dałby możliwości porównania z dostarczonym przez doktora Patonaya mitochondrialnym DNA, pobranym z zęba czaszki z Györ. Nie było więc możliwości upewnienia się, że są to fragmenty tej samej czaszki. Przy pomocy metody datowania radiowęglowego owe fragmenty zostałyby bezpowrotnie utracone, w zamian zaś uzyskano by w najlepszym wypadku zbieżność jedynie co do chronologii, a nie dającą pewność, iż są to fragmenty czaszki tej samej osoby. W tej sytuacji zdecydowano, by na razie nie poddawać interesujących fragmentów datowaniu radiowęglowemu i czekać na wdrożenie metod, które być może pozwolą kiedyś osiągnąć pewniejsze wyniki. Ks. dr Lukácsi, po konsultacjach, zaznaczył, że znalezione fragmenty, wobec zaistniałych okoliczności nie mogą też stanowić przedmiotu kultu religijnego. $\mathrm{O}$ wynikach powiadomiono biskupa płockiego Piotra Liberę.

Ciekawe wyniki przyniosły natomiast badania pozostałych znalezionych w Pułtusku artefaktów,
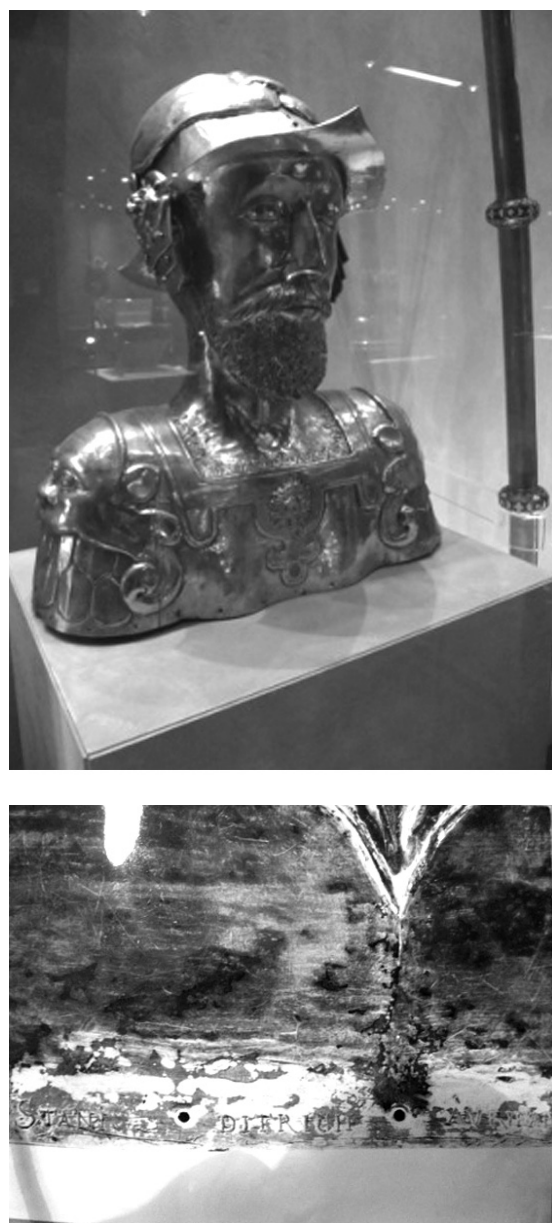

Il. 5 i 6. Relikwiarz hermowy św. Władystawa (?). Fot. Autor to jest poduszek. Wszystkie one zostały wykonane z duża starannością. Wypełnienie pochodzenia organicznego obszyto najpierw starannie wykonanym płótnem o rzadkim splocie. Następnie powleczono je drogimi, jedwabnymi powłokami, zszywanymi kosztownymi nićmi. Na trzeciej z poduszek wykonano ze złoconej folii ornamenty w postaci gwiazd z cienkimi złoceniami. Te ustalenia pozwalają stwierdzić, że do odnalezionych artefaktów przywiązywano niegdyś dużą wagę i wykonano je z dużą starannością, nie szczędząc środków. Pozwala to z dużą dozą prawdopodobieństwa sądzić, iż badane przedmioty były uznawane i czczone w Pułtusku jako relikwie św. Władysława, dokładnie tak, jak to potwierdzał łaciński napis na wstęgach. Można jedynie przypuszczać, że owe siedem najstarszych fragmentów czaszki, może pochodzić z widocznego na czaszce z Györ brutalnego odłupania kilku kawałków, ale obecnie pewności mieć nie można. Obecność innych kości tłumaczyć chyba trzeba faktem, że w owym znalezisku oryginalne 
fragmenty nie bardzo nadawały się do eksponowania, zwłaszcza z daleka czy w czasie procesji. Wobec tego jezuici „dołożyli” nieco innych kości tak, by relikwie wyglądały okazale.

Została jeszcze do rozwikłania sprawa hermy czy może obu herm podarowanych jezuitom w I635 roku przez Władysława IV i ochmistrzynię dworu Zygmunta III Urszulę Meierin. Łatwiejsza do identyfikacji wydaje się sprawa drugiego z relikwiarzy. Otóż srebrny, złocony i w partii naszyjnika inkrustowany kamieniami relikwiarz hermowy św. Urszuli, o wymiarach: wysokość $43,3 \mathrm{~cm}$ i głębokość I8,5 cm oraz podstawie $(40,2 \mathrm{~cm} \times \mathrm{I} 6 \mathrm{~cm})^{35}$, przechowywany jest dziś w skarbcu Muzeum Diecezjalnego w Płocku (il. 4). Jest on datowany na początek XVII stulecia. Pod głową w relikwiarzu umieszczona była kartka papieru pisana atramentem o treści: X. [iądz] Pniewski /K.K. P.D.K/ Puttusk $1840^{36}$. Wskazuje to na proweniencję relikwiarza, czyli Pułtusk, oraz fakt, że relikwiarz na pewno otwierano w I840 roku. Ksiądz Pniewski to kanonik katedralny płocki, prałat kapituły kolegiackiej pułtuskiej, od I830 roku dziekan pułtuski i proboszcz kolegiaty p.w. Zwiastowania NMP w Pułtusku ${ }^{37}$. Zmarł w I858 roku, a jego znaczenie w lokalnej społeczności upamiętnia epitafium w dzisiejszej bazylice kolegiackiej ${ }^{38}$. Potwierdza to wcześniejsze przypuszczenia, iż precjoza z kościoła pojezuickiego po kasacie zakonu trafiły do skarbca pułtuskiej kolegiaty, gdzie były jeszcze w połowie XIX wieku. Następnie przekazano je do Muzeum Diecezjalnego w Płocku. Czas powstania relikwiarza, zgodność z opisanymi wcześniej faktami, dedykacja św. Urszuli, wskazują z bardzo wysoką dozą prawdopodobieństwa, iż jest to właśnie relikwiarz przekazany przez Urszulę Meierin w czasie jej wizyty w Pułtusku z królem Władysławem IV w I635 roku.

Zdecydowanie bardziej kłopotliwa była identyfikacja relikwiarza hermowego podarowanego przez Władysława IV. Uwagę wzbudził przechowywany także w Skarbcu Muzeum Diecezjalnego w Płocku relikwiarz hermowy podpisany jako relikwiarz św. Maurycego. Wykonano go ze złoconego srebra. Ma on wymiary: wysokość $-42 \mathrm{~cm}$, głębokość - 24,5 cm i podstawa $-38,3 \times 15,4 \mathrm{~cm}$. U dołu na plecach jest on sygnowany: STANI/SLAUS/: DITRICH AURIFABER R.P. FECIT ANNO I600 39 (il. 5 i 6).

Jednakże jeszcze istotniejszym okazała się inna informacja. Otóż podobnie jak w przypadku relikwiarza św. Urszuli, wewnątrz interesującej nas hermy znajdowała się wypisana atramentem kartka papieru z napisem: X.[iadz] Pniewski/K.K. P.D.K/ Pult/usk/IO4o (sic!)40. By ponownie nie powielać przedstawionego wyżej komentarza, stwierdźmy więc od razu iż herma także w latach czterdziestych XIX stulecia przechowywana była w Pułtusku i znajdowała się w gestii ks. Pniewskiego. Problemem pozostaje fakt, iż wizerunek miał przedstawiać św. Maurycego. O przechowywaniu jego relikwii w Pułtusku do XIX wieku nic jednak nie wiadomo.

Cechy i atrybucja wizerunku nie dają podstaw do jednoznacznej identyfikacji. Renesansowa zbroja, morion(?) na głowie, dalekie są od typowych atrybutów św. Maurycego: rysom daleko do afrykańskich, popiersiu w sposób oczywisty brak jest słynnej włóczni,

\footnotetext{
35 Muzeum Diecezjalne w Płocku (dalej: MDP), Karta inwentaryzacyjna zabytku nr 137480.

36 Tamże.

37 J. Ziółek, Diecezja płocka w latach 1832-1863, „Studia Płockie”, 3/1975, s. 297.

38 J. Młodyński, Pniewski Jan Tomasz (1776-1858), w: T. Kowalski, J. Młodyński, J. Szczepański, Wpisani w historię Pultuska. Stownik biograficzny, Pułtusk 2001, s. 230-231.

39 MDP, Karta inwentaryzacyjna zabytku nr 137484.

40 Tamże.
} 
miecza, konia, gałązki palmowej czy motywu orła. Zamiast niego widoczny jest zaś lew. Za to postać na hermie, bez względu na to kogo przedstawia, spełnia kryterium, iż może ona rzeczywiście nieco przypominać ówczesny wizerunek króla Władysława IV, tak jak to zapisali jezuici pułtuscy. Długoletni kustosz Muzeum Diecezjalnego w Płocku, ks. kan. Stefan Cegłowski także zwrócił na te fakty uwagę, ale nie udało się ustalić kto, dlaczego i kiedy przypisał ową hermę św. Maurycemu. Dopiero kiedy wymiary hermy zostały skonfrontowane z wymiarami odnalezionych w Pułtusku poduszek, okazało się, że trzy ułożone na sobie artefakty mają wymiary pozwalające niemal idealnie ulokować je w hermie ${ }^{41}$. Wówczas sprawa stała się jasna.

Analizowana herma pochodzi z Pułtuska, podobnie jak herma św. Urszuli znajdowała się w gestii proboszcza kolegiaty ks. J. Pniewskiego w I840 roku, nie ma atrybucji pozwalającej jednoznacznie stwierdzić, iż jest to św. Maurycy, za to pozwala się odczytać jako wizerunek Władysława IV. Tak jak to wspominali jezuici została wykonana ze srebra i to w czasie, który umożliwiał jej przekazanie do Pułtuska. Wreszcie wymiary poduszek pozwalają na dość precyzyjne ułożenie ich w hermie. Z dużą dozą prawdopodobieństwa można więc stwierdzić, iż jest to właśnie ta herma, którą w I635 roku ofiarował król Rzeczypospolitej Władysław IV Waza z przeznaczeniem na przechowywanie w niej relikwii króla Węgier św. Władysława.

\section{St. Ladislaus in Pultusk \\ Summary}

The article deals with the fate of the relics of Saint Władysław donated in 1585 by the Polish queen Anna Jagiellonka to the Jesuit college in Pułtusk. They were handed over from the royal treasury as evidence of gratitude for the education of Andrzej Batory - nephew of King Stephen I. Later the members of the Waza dynasty: princess Anna Katarzyna (I634) and king Władysław IV Waza (I635), fond homage to these relics. At that time he also gave them a silver reliquary as a gift. After the suppression of the Jesuits, the fate of the relics was unknown. Artifacts connected associated with them were found in the church of Saint Peter and Paul in Pułtusk in 20I6. Research was unable to confirm that 7 of the oldest parts of a skull came from Saint Władysław’s skull which is now kept in Györ (lack of the DNA in the parts from Pułusk). Later, it was confirmed that these artifacts venerated in Pułtusk were relics of Saint Władysław. On the basis of the source analysis and comparison of the size of herms and pillows the author fixed that this herm, which was kept in Diocesan Museum in Płock, known as herm Saint Maurycy`s herm is in fact the herm donated to the Pułtusk`s Jesuits by Władysław IV in I635 on Saint Władysław`s relics.

Keywords: St. Ladislaus- relics, St. Ladislaus- worship, St. Ladislaus's polish reliquary, Pułtusk- Jesuits College, King Władysław IV Vasa

41 Herma ma wymiary: wysokość - $42 \mathrm{~cm}$, głębokość - 24,5 cm i podstawa - 38,3 x 15,4 cm. Trzy poduszki tworzą zaś bryłę łącznie wysoką na około $18 \mathrm{~cm}(3 \times 6 \mathrm{~cm})$, mieszcząc się w ramionach hermy, długie w podstawie na $77 \mathrm{~cm}$ i szerokie na 12,12 i $11 \mathrm{~cm}$. 


\section{BIBLIOGRAFIA}

I. Źródła

A. Archiwalne

Archiwum Romanorum Societatis Iesu:

Polonia 50, Annuae et historiae Poloniae I550-I660.

Archiwum Rzymsko-Katolickiej Parafii św. Jana Pawła II w Pułtusku:

Protokół przekazania kościoła pod wezwaniem św. Piotra i Pawła wraz z domem parafialnym, garażami i działka, na której te obiekty zostały zbudowane, mps.

Muzeum Diecezjalne w Płocku:

Karta inwentaryzacyjna zabytku nr 137480.

Karta inwentaryzacyjna zabytku nr 137484.

B. Drukowane

Annuae Litterae Sosietatis Jesu 1585. Provincia Poloniae, Romae 1587.

Monumenta Poloniae Vaticana, t. IV: I.A. Caliagri Nuntii Apos.[tolici] in Polonia epistolas et acta 1578-158I, oprac. L. Boratyński, Kraków I9I5.

Monumenta Poloniae Vaticana, t. V: Alberti Bolonetti Nuntii Apostolici in Polonia epistolarum et actorum partem I: aa. I58I-I582, oprac. E. Kuntze C. Nanke, Kraków I923-33.

Monumenta Poloniae Vaticana, t. VI: Alberti Bolonetti Nuntii Apostolici in Polonia epistolarum et actorum pars II: a. I583, oprac. E. Kuntze, Kraków 1938.

Volumina Constitutionum, t. II: I550-I609, Volumen I: I550-I585, oprac. S. Grodziski, I. Dwornicka i W. Uruszczak, Warszawa 2005.

2. Opracowania

Encyklopedia wiedzy o jezuitach na ziemiach Polski i Litwy 1564-1995, oprac. L. Grzebień SJ i in., Kraków 2004.

Gorys E., Leksykon świętych, Warszawa 2007.

Horn I., Andrzej Batory, Warszawa 2010.

Kuźmina D., Jakub Wujek (I54I-I597) pisarz, ttumacz i misjonarz, Warszawa 2004.

Lipka C., Święty król węgierski Władysław, „Quo Vadis?”, 47/20I7, s. 3-I5.

Lipka C., Święty król węgierski Władysław, w: Węgry-Polska, wspólne dziedzictwo, red. J. Zimny, Sandomierz 2007, s. 315-329.

Lolo R., Kolegium jezuickie w Puttusku pod koniec XVIII wieku. Przyczynek do historii zespotu architektonicznego, w: Polska-Europa-Afryka. Studia ofiarowane Profesorowi Bronisławowi Nowakowi w sześćdziesiata piąta rocznicę urodzin, red. M. Dygo et al., Pułtusk 2007, s. 77-86.

Lolo R., Ksiadz Piotr Skarga SJ w Pułtusku. Fragment biografii na tle dziejów miasta, w: Piotr Skarga SJ - kaznodzieja z Mazowsza, red. A. Koseski, R. Lolo, Pułtusk 20I3, S. $6 \mathrm{I}-82$.

Lolo R., Kult św. Stanisława Kostki w diecezji płockiej do I773 r., w: Zwykli niezwykli. Kult świętych $w$ diecezji łomżyńskiej. Katalog wystawy, red. B. Kalinowska, K. Mróz, Ostrołęka 20I6, s. 83-90.

Lolo R., Oświata w Rzeczypospolitej w czasach panowania Stefana Batorego ze szczególnym uwzględnieniem jezuitów, w: Stefan Batory - król Rzeczypospolitej i książę Siedmiogrodu. 
Báthory István lengyel király ès erdèlyi Fejedelem, red. A. Körmendy, R. Lolo, Pułtusk 2008.

Lolo R., Powstanie i rozwój kolegium jezuickiego w Puttusku za posługi biskupiej Andrzeja Noskowskiego, w: Renesans na Mazowszu. Andrzej Noskowski-biskup płocki, red. A. Koseski, K. Ostrowski, L. Sobieraj, Pułtusk-Płock 201 .

Lolo R., Towarzystwo Jezusowe w diecezji płockiej 1566-I773. Studium koegzystencji w dobie recepcji reformy trydenckiej, Pułtusk 2013.

Mandziuk S., Kościelne dzieje Bielan warszawskich, „Saeculum Christianum”, 2/200o, s. 5I-65.

Młodyński J., Pniewski Jan Tomasz (I776-I858), w: T. Kowalski, J. Młodyński, J. Szczepański, Wpisani w historię Puttuska. Stownik biograficzny, Pułtusk 200I, s. 230-23I.

Nastalska-Wiśnicka J., Władysław I, Laszlo, Ladislaus, w: Encyklopedia katolicka, t. 20, Lublin 20I4, k. 745 .

Paszenda J. SJ, Budowle jezuickie w Polsce XVI-XVIII w., t. 2, Kraków 2000.

Piechnik L. SJ, Dzieje Akademii Wileńskiej, t. I: Początki Akademii 1570-I599, Rzym I984. Wołosz A. K. F., Opis kościoła pojezuickiego w Pułtusku z I775 r., „Studia Mazowieckie”, 3/I998, z. I-2, s. I04-II9.

Wykaz relikwii w diecezji płockiej, „Miesięcznik Pasterski Płocki”, I927, nr 2.

Ziółek J., Diecezja płocka w latach I832-I863, „Studia Płockie”, 3/I975. 